\title{
UDZIAŁ ORGANIZACJI EKOLOGICZNYCH W OCHRONIE ŚRODOWISKA A GRANICE REALIZACJI PRZEZ NIE PRAWA DO UDZIAŁU W POSTĘPOWANIU WYMAGAJĄCYM UDZIAŁU SPOŁECZEŃSTWA
}

\section{Wstęp}

Partycypacja organizacji ekologicznych w ochronie środowiska ma kluczowe znaczenie w zakresie prawa do udziału w postępowaniu wymagającym udziału społeczeństwa. Podmioty te w postępowaniu administracyjnym, sądowo-administracyjnym oraz sądowym ${ }^{1}$ występują $\mathrm{w}$ interesie publicznym, posiadając legitymację procesową. Podstawa legitymacji procesowej zależy jednak od tematyki decyzji, działania lub zaniechania sądu czy innego podobnego do sądu podmiotu, które mogą zostać zakwestionowane. Udział takiego podmiotu w powyższych postępowaniach będzie dość rozległy, gdyż pojęcia ochrony środowiska ${ }^{2}$ oraz ochrony przyrody są terminami pojemnymi.

* Dr hab., Uniwersytet Szczeciński; e-mail: anna.barczak@usz.edu.pl, https:/ /orcid.org/ 0000-0002-7412-719X.

1 Szerzej na temat udziału organizacji pozarządowych w postępowaniu w sprawach cywilnych z zakresu ochrony środowiska zob. K. Flaga-Gieruszyńska, Udział organizacji pozarzadowych w postępowaniu w sprawach cywilnych z zakresu ochrony środowiska, w: Administracja a środowisko. Prace dedykowane prof. zw. dr. hab. Markowi Górskiemu z okazji jubileuszu 45-lecia pracy naukowej, red. A. Barczak, P. Korzeniowski, Szczecin 2018, s. 393 i n.

2 Na temat pojęć „ochrona środowiska” i „środowisko” zob. art. 3 pkt 13 i pkt 39 ustawy z dnia 27 kwietnia 2001 r. - Prawo ochrony środowiska, tekst jednolity: Dz. U. z 2020 r. poz. 1219 z późn. zm.; M. Górski, M. Pchałek, W. Radecki, J. Jerzmański, M. Bar, S. Urban, J. Jendrośka, Prawo ochrony środowiska. Komentarz, Warszawa 2019, s. 61-62, 85-87; M. Górski, w: Ustawa - Prawo ochrony środowiska. Komentarz, red. J. Jendrośka, Wrocław 2001, s. 53-57, 81-83; B. Rakoczy, w: Leksykon ochrony środowiska, red. J. Ciechanowicz-McLean, 
W działalności organizacji ekologicznych dochodzi czasami do nadużyć prawa publicznego ${ }^{3}$, dlatego też regulacje prawne powinny zawierać unormowania utrudniające nielegalne działanie tego typu organizacji. Celem niniejszego opracowania jest zatem zbadanie, czy środki prawne hamujące działania niezgodne z prawem tytułowego podmiotu istnieją, a jeżeli tak, to czy są wystarczające. Pomocne przy tym będzie uzyskanie odpowiedzi na dwa pytania:

1. Na jakiej konkretnej podstawie i na jakich warunkach organizacje ekologiczne mogą uzyskać legitymację procesową?

2. Jaki jest zakres kontroli i nadzoru organu administracji wobec organizacji ekologicznych?

Aby zrealizować zamierzony cel oraz otrzymać odpowiedzi na powyższe pytania, w pierwszej kolejności zostaną przeanalizowane wymagania, jakie są konieczne do uzyskania przez organizacje ekologiczne legitymacji procesowej ${ }^{4}$. Z kolei druga część będzie dotyczyć przedstawienia granic realizowania przez organizacje ekologiczne partycypacji w postępowaniu środowiskowym w interesie publicznym. Granice te będą wyznaczały środki kontrolno-nadzorcze stosowane przez odpowiednie organy administracji wobec organizacji ekologicznych.

\section{Zasady działania organizacji ekologicznych w prawie polskim}

Pod pojęciem organizacji ekologicznej rozumie się organizację społeczną, której statutowym celem jest ochrona środowiska (art. 3 ust. 1 pkt 10 ustawy o udostępnianiu informacji o środowisku i jego ochronie, udziale społeczeństwa w ochronie środowiska oraz o ocenach oddziaływania na

Warszawa 2009, s. 164-167, 373-378; wyrok WSA w Kielcach z dnia 4 grudnia 2013 r., II SA/Ke 920/13, LEX nr 1426855.

3 J. Parchomiuk, Nadużycie prawa w prawie administracyjnym, Warszawa 2018, s. $161 \mathrm{i} \mathrm{n}$.

4 Szerzej zob. A. Barczak, M. Łazor, A. Ogonowska, Oceny oddziaływania na środowisko w prawie polskim ze wzorami dokumentów i schematami, Warszawa 2018, s. 133 i n. oraz A. Barczak, A. Ogonowska, Wykładnia przepisów w zakresie udziału społeczeństwa w ochronie środowiska - wybrane problemy, Studia Prawnicze KUL 2018, nr 3, s. 17-22. 
środowisko $\left.{ }^{5}\right)^{6}$. Z kolei termin „organizacja społeczna” został zdefiniowany w art. $5 \S 2$ pkt 5 Kodeksu postępowania administracyjnego ${ }^{7}$. Według przywoływanej regulacji przez organizacje społeczne rozumie się w postępowaniu administracyjnym organizacje zawodowe, samorządowe, spółdzielcze i inne organizacje społeczne.

Za trafne uznać należy cechy organizacji ekologicznych zaproponowane przez K. Gruszeckiego ${ }^{8}$. Autor zauważa, że podmioty takie muszą być wyodrębnione organizacyjnie, działać legalnie oraz prowadzić działalność w zakresie ochrony środowiska przez minimum 12 miesięcy przed dniem wszczęcia postępowania9. Nie ma znaczenia miejsce ich działalności oraz wykazywanie interesu społecznego ${ }^{10}$.

Dla uzyskania legitymacji procesowej przez organizacje ekologiczne kluczowe znaczenie ma przedmiot działalności, odróżniający je od innych organizacji społecznych. Działalność w zakresie ochrony środowiska nie musi stanowić jedynego celu statutowego ${ }^{11}$. Może dotyczyć rozlegle rozumianej ochrony środowiska lub ochrony przyrody. Dlatego też tak istotne jest posiadanie statutu ${ }^{12}$. Terminu „statut” nie należy rozumieć literalnie. Wykładnia celowościowa pozwala na zastosowanie tego określenia sensu

5 Ustawa z dnia 3 października 2008 r. o udostępnianiu informacji o środowisku i jego ochronie, udziale społeczeństwa w ochronie środowiska oraz o ocenach oddziaływania na środowisko, tekst jednolity: Dz. U. z 2021 r. poz. 247.

6 A. Lipiński, Prawne podstawy ochrony środowiska, Warszawa 2010, s. 75. Zob. też D. Trzcińska, Pojęcie organizacji ekologicznej. Glosa do wyroku WSA w Krakowie z dnia 14 kwietnia 2010, II SA/Kr 1774/09, Gdańskie Studia Prawnicze - Przegląd Orzecznictwa 2011, nr 2.

7 Ustawa z dnia 14 października 1960 r. - Kodeks postępowania administracyjnego, tekst jednolity: Dz. U. z 2020 r. poz. 256 z późn. zm. (dalej: K.p.a.).

8 K. Gruszecki, Ustawa o udostęnnianiu informacji o środowisku i jego ochronie, udziale społeczeństwa w ochronie środowiska oraz o ocenach oddziaływania na środowisko. Komentarz, Wrocław 2009, s. 118-119.

9 Wyrok WSA w Gorzowie Wielkopolskim z dnia 13 października 2017 r., II SA/Go 889/17, LEX nr 2387827; wyrok NSA z dnia 19 stycznia 2018 r., II OSK 833/16, LEX nr 2452817.

10 Wyrok WSA w Szczecinie z dnia 6 kwietnia 2017r., IISA/Sz 1026/16, LEX nr 2281820.

11 W. Jacyno, J. Rewkowska, w: Ustawa o udostępnianiu informacji o środowisku i jego ochronie, udziale społeczeństwa w ochronie środowiska oraz o ocenach oddziaływania na środowisko. Komentarz, red. T. Filipowicz, A. Plucińska-Filipowicz, M. Wierzbowski, Warszawa 2017, s. 52-53.

12 Na temat rozwoju organizacji ekologicznych zob. A. Haładyj, Organizacje społeczne i ekologiczne w postępowaniu w sprawie ochrony środowiska w latach 1980-2000, w: Administracja a środowisko. Prace..., s. 379 i n. 
largo. Pod tym pojęciem będziemy zatem rozumieć każdy akt wewnętrzny (ustrojowy) o charakterze założycielskim określający strukturę, zadania i sposób działania instytucji lub organizacji. Może to być np. regulamin czy umowa założycielska.

W momencie gdy organizacja ekologiczna spełni powyższe wymagania, może zgłosić chęć uczestnictwa w postępowaniu wymagającym udziału społeczeństwa ${ }^{13}$. Zdaniem Wojewódzkiego Sądu Administracyjnego w Lublinie ${ }^{14}$ przepis art. 44 ust. 1 ustawy o udostępnianiu informacji o środowisku i jego ochronie, udziale społeczeństwa w ochronie środowiska oraz o ocenach oddziaływania na środowisko ma zastosowanie do udziału organizacji ekologicznej tylko w postępowaniach regulowanych przepisami tej ustawy. W innych postępowaniach, do których stosuje się przepisy omawianej ustawy, niewymagających udziału społeczeństwa, przepis ten nie może mieć zastosowania, lecz podstawę materialnoprawną orzekania o dopuszczeniu do udziału w postępowaniu organizacji społecznej stanowi art. $31 \S 1$ K.p.a.

Wątpliwości budzi fakt, że ustawodawca nie określił formy zgłoszenia oraz jego wymagań formalnych. Ze względu na to, że jest to rodzaj postępowania administracyjnego, zastosowanie ma art. $63 \S 1$ K.p.a. Zgodnie z nim podania (zgłoszenie jest jedną z jego form) mogą być wnoszone na piśmie, telegraficznie lub za pomocą dalekopisu, telefaksu, poczty elektronicznej albo za pomocą formularza umieszczonego na stronie internetowej właściwego organu administracji publicznej, umożliwiającego wprowadzenie danych do systemu teleinformatycznego tego organu, a także ustnie do protokołu. Zgłoszenia dokonuje podmiot właściwy do reprezentowania wnoszącej go organizacji w obrocie prawnym. Wymagania formalne reguluje art. 63 § 3 i 3a K.p.a. Organizacja ekologiczna nie może jednak dokonać wyboru podstawy prawnej dopuszczenia do udziału w postępowaniu. Wezwanie przez organ organizacji społecznej zgłaszającej wniosek o dopuszczenie do udziału w postępowaniu wymagającym

13 Wyrok WSA w Rzeszowie z dnia 30 maja 2017 r., II SA/Rz 31/17, LEX nr 2366927; wyrok NSA z dnia 10 marca 2015 r., II OSK 1919/13, LEX nr 1666090; B. Draniewicz, Udziat organizacji ekologicznej w postepowaniu niewymagajacym udziału społeczeństwa, Prawo i Środowisko 2010, nr 3, s. 115 i n.; tenże, Uprawnienia organizacji ekologicznych w postepowaniach wymagających udziału społeczeństwa, Monitor Prawniczy 2011, nr 1, s. 12 i n.; A. Wilk-Ilewicz, Udziat społeczeństwa w procesie uzyskania decyzji środowiskowej, Zeszyty Naukowe Sądownictwa Administracyjnego 2015, nr 5, s. 67 i n.

14 Wyrok WSA w Lublinie z dnia 9 maja 2019 r., II SA/Lu 826/18, LEX nr 2679152. 
udziału społeczeństwa do określenia podstawy wniosku oznacza, że organ dopuszcza wybór podstawy prawnej rozpoznania wniosku, a jest to wbrew obowiązującej regulacji art. 44 ust. 1 ustawy o udostępnianiu informacji o środowisku i jego ochronie, udziale społeczeństwa w ochronie środowiska oraz o ocenach oddziaływania na środowisko ${ }^{15}$. Organ administracji dopuszczając organizację ekologiczną do udziału w postępowaniu, nie ma obowiązku wydania postanowienia ${ }^{16}$. $Z$ kolei odmowa jest już sformalizowana. Przyjmuje postać postanowienia wydanego przez właściwy organ administracji. Na postanowienie to organizacji ekologicznej służy zażalenie (art. 44 ust. 4 ustawy o udostępnianiu informacji o środowisku i jego ochronie, udziale społeczeństwa w ochronie środowiska oraz o ocenach oddziaływania na środowisko) ${ }^{17}$. Istotne jest to, że może ona przystąpić do postępowania na każdym jego stadium. Warunkiem sine qua non jest, jak wskazano powyżej, statutowe zainteresowanie sprawami ochrony środowiska czy ochrony przyrody ${ }^{18}$.

Organizacja ekologiczna dopuszczona do właściwego postępowania występuje w nim na prawach strony (art. 44 ust. 1 ustawy o udostępnianiu informacji o środowisku i jego ochronie, udziale społeczeństwa w ochronie środowiska oraz o ocenach oddziaływania na środowiska) ${ }^{19}$. Organizacja nie jest stroną takiego postępowania. $Z$ mocy prawa przysługują jej jednak wszelkie uprawnienia procesowe strony, wynikające z K.p.a. W związku

15 Wyrok NSA z dnia 9 kwietnia 2019 r., II OSK 1294/17, Legalis nr 1916107.

16 Wyrok WSA we Wrocławiu z dnia 27 maja 2010 r., II SA/Wr 89/10, LEX nr 674622.

17 M. Jabłoński, Realizacja przez administracje publiczna prawa udziału społeczeństwa w postępowaniu w sprawie ochrony środowiska, w: Ocena modelu prawnego organizacji ochrony środowiska w Polsce i na Słowacji, red. E. Ura, J. Stelmasiak, S. Pieprzny, Rzeszów 2012, s. 319.

18 B. Draniewicz, Glosa do wyroku WSA w Krakowie z 22.07.2012 r. II Sa/Kr 272/10, Prawo i Środowisko 2010, nr 3, s. 111.

19 Wyrok WSA w Kielcach z dnia 30 sierpnia 2017 r., II SA/Ke 364/17, LEX nr 2357787; wyrok NSA z dnia 13 stycznia 2016 r., II OSK 1131/14, LEX nr 2033961; P. Milewski, Status prawny organizacji ekologicznych w ujęciu porównawczym, Kwartalnik Prawa Publicznego 2008, t. 8, nr 3-4, s. 197 i n.; W. Federczyk, Organizacja ekologiczna jako uczestnik postępowania administracyjnego w zakresie ochrony środowiska, Kwartalnik Prawa Publicznego 2008, t. 8, nr 3-4, s. 77; J. Borkowski, Glosa do wyroku NSA z dnia 23 listopada 1999 r., II SA Kr 1191/99, OSP 2000, z. 7-8, poz. 112; M. Górski, Aktualne regulacje prawne w zakresie ochrony środowiska wedtug stanu prawnego na koniec stycznia 2009 r., Poznań 2009, s. 26. 
z tym może wykonywać wszystkie czynności procesowe z takim samym skutkiem, jak gdyby zostały one dokonane przez stronę ${ }^{20}$.

Organizacja ekologiczna posiada określone środki prawne. Wymienia je art. 44 ust. 2 i 3 ustawy o udostępnianiu informacji o środowisku i jego ochronie, udziale społeczeństwa w ochronie środowiska oraz o ocenach oddziaływania na środowisko ${ }^{21}$. Są to: prawo złożenia odwołania od decyzji oraz skarga do sądu administracyjnego na decyzję. Ten ostatni instrument prawny budzi pewne kontrowersje w literaturze przedmiotu ${ }^{22}$.

Polskie regulacje prawne dopuszczają możliwość prowadzenia działalności przez organizacje ekologiczne $\mathrm{w}$ różnych formach prawnych ${ }^{23}$. Najczęściej przyjmują one postać stowarzyszenia czy fundacji ${ }^{24}$. Organizacją ekologiczną nie mogą być natomiast partie polityczne ${ }^{25}$, izby gospodarcze, jednostki pomocnicze samorządu gminnego, samorząd pracowniczy, jednostki ochotniczej straży pożarnej oraz związki zawodowe ${ }^{26}$.

20 W. Chróścielewski, J.P. Tarno, Postępowanie administracyjne. Zagadnienia podstawowe, Warszawa 2002, s. 68.

21 P. Daniel, Udział organizacji ekologicznej w postępowaniu w przedmiocie wydania decyzji o pozwoleniu na budowe, Przegląd Prawa Ochrony Środowiska 2012, nr 4, s. 9-28.

22 Szerzej zob. M. Górski, Aktualne regulacje..., s. 27.

23 Dla przykładu można wskazać na działalność organizacji międzynarodowych, takich jak: Greenpeace International, World Wide Fund for Nature, BirdLife International, People for the Ethical Treatment of Animals (PETA), World Society for the Protection of Animals (WSPA); z organizacji polskich natomiast: Fundacja Nasza Ziemia, Fundacja Wspierania Inicjatyw Ekologicznych, Liga Ochrony Przyrody, Towarzystwo na rzecz Ziemi.

24 Uchwała siedmiu sędziów NSA z dnia 12 grudnia 2005 r., II OPS 4/05, ONSAiWSA 2006, z. 2, poz. 37. Pozytywnie ocenia: J.P. Tarno, Glosa do uchwaty siedmiu sędziów Naczelnego Sadu Administracyjnego z dnia 12 grudnia 2005 r. (sygn. akt II OPS 4/05) (udziat fundacji jako organizacji społecznej w postępowaniu sądowym), Zeszyty Naukowe Sądownictwa Administracyjnego 2006, nr 1, s. 150 i n.; I. Skrzydło-Niżnik, Glosa do uchwały NSA z dnia 12 grudnia 2005 r., II OPS 4/05, Przegląd Sejmowy 2006, nr 2, s. 128-139; A. Zieliński, Udziat fundacji w postępowaniu sadowoadministracyjnym. Glosa do uchwaty NSA z dnia 12 grudnia 2005 r., II OPS 4/05, Państwo i Prawo 2006, z. 8, s. 122-126. Krytycznie stanowisko NSA ocenia T. Bąkowski, Uznanie fundacji za organizacje społeczna w postępowaniu przed sadami administracyjnymi. Glosa do uchwaty NSA z dnia 12 grudnia 2005 r., II OPS 4/05, Gdańskie Studia Prawnicze - Przegląd Orzecznictwa 2007, nr 2, s. 53-60.

25 Por. B. Opaliński, w: Ustawa o udostępnianiu informacji o środowisku i jego ochronie, udziale społeczeństwa w ochronie środowiska oraz o ocenach oddziatywania na środowisko. Komentarz, red. B. Opaliński, Warszawa 2016, s. 91-92. Podobny pogląd wyraził W. Radecki, zob. tenże, w: Ustawa o ochronie i kształtowaniu środowiska. Komentarz, red. J. Sommer, t. 1, Wrocław 1999, s. 503.

26 K. Gruszecki, Ustawa o udostępnianiu informacji..., s. 120. 
Te ostatnie podmioty $\mathrm{w}$ art. 45 ustawy o udostępnianiu informacji o środowisku i jego ochronie, udziale społeczeństwa w ochronie środowiska oraz o ocenach oddziaływania na środowisko zostały wymienione obok organizacji ekologicznych jako współdziałające z organami administracji w dziedzinie ochrony środowiska.

\section{Granice realizowania przez organizacje ekologiczne prawa do uczestniczenia $\mathrm{w}$ postępowaniu $\mathrm{w}$ interesie publicznym}

Organizacje ekologiczne działając w sprawach związanych $\mathrm{z}$ ochroną środowiska, dopuszczają się niekiedy nadużyć w zakresie prawa do sądu czy wobec podmiotów podobnych do sądu. Czasami organizacje te korzystają $\mathrm{z}$ tego prawa w sposób nie do końca przemyślany. Zdarzają się protesty wobec określonych inwestycji, przyjmujące różną postać, np. blokad oraz innych działań bezpośrednich (często polegających na naruszeniu konkretnych przepisów prawa), akcje polegające na wysyłaniu pism i protestów. Dochodzi także do konfliktów ukrytych pod postacią uczestnictwa $\mathrm{w}$ postępowaniu administracyjnym oraz korzystania $\mathrm{z}$ dostępnych form i możliwości prawnych. Największa ilość konfliktów dotyczy gospodarki odpadami, form ochrony przyrody (zwłaszcza obszarów Natura 2000) oraz działań w zakresie praw zwierząt (np. akcje antycyrkowe) ${ }^{27}$. Udział organizacji ekologicznych $\mathrm{w}$ procesie przygotowywania i realizacji inwestycji to nieodzowny element polskiej rzeczywistości. Niestety, działania ekologów zrzeszonych w organizacjach ekologicznych czasem odbierane są jako utrudniające ważne projekty, których realizacją zainteresowani są nie tylko inwestorzy, lecz także nierzadko jednostki samorządu terytorialnego.

W związku z powyższym rodzi się pytanie: czy aktualne regulacje prawne przewidują środki kontrolno-nadzorcze czy też inne instrumenty prawne stosowane wobec organizacji ekologicznych nadużywających swych praw? Udzielenie na nie odpowiedzi nie jest łatwe, bowiem prawo polskie nie zna terminu "nadużycia prawa publicznego", jakim jest występowanie $\mathrm{w}$ interesie środowiska. Instrumenty te nie występują $\mathrm{w}$ postępowaniu administracyjnym, sądowym czy sądowo-administracyjnym

27 H. Lisicka, Organizacje ekologiczne a prawo, w: Księga Pamiątkowa Profesora Ryszarda Paczuskiego, red. Z. Bukowski, Toruń 2004, s. 246. 
(tzn. nie ma ich ani w ustawie Prawo ochrony środowiska, K.p.a., Kodeksie postępowania karnego ${ }^{28}$, Kodeksie postępowania cywilnego ${ }^{29}$, ani w ustawie Prawo o postępowaniu przed sądami administracyjnymi ${ }^{30}$ ). Formułując odpowiedź na powyższe pytanie, należy zatem zwrócić uwagę na przepisy prawne regulujące działalność samych organizacji, gdyż ustawa o udostępnianiu informacji o środowisku i jego ochronie, udziale społeczeństwa $\mathrm{w}$ ochronie środowiska oraz o ocenach oddziaływania na środowisko nie reguluje wskazanych wyżej kwestii. Dlatego też należy sięgnąć do przepisów ogólnych, tj. do ustawy Prawo o stowarzyszeniach ${ }^{31}$ oraz ustawy o fundacjach ${ }^{32}$.

Organizacje ekologiczne w postępowaniu administracyjnym, sądowym czy sądowo-administracyjnym realizują swoje uprawnienia $\mathrm{w}$ interesie publicznym. Podmioty te stoją na straży zachowania istniejących warunków środowiska, a także podejmują działania o charakterze politycznym, informacyjnym czy edukacyjnym ${ }^{33}$. W aspekcie realizacji przez nie celów publicznych, w tym także zadań publicznych, określonym organom administracji przysługują względem tych organizacji kompetencje mające na celu weryfikację prawidłowości prowadzonych w tym zakresie działań. Analizowane instrumenty przyjmują postać nadzoru. Granice samodzielności działania rzeczonych podmiotów wyznaczają natomiast środki nadzoru stosowane przez określone organy administracji, występujące jako organy nadzorujące. Zaznaczyć wypada, że regulacje ustawy Prawo o stowarzyszeniach oraz ustawy o fundacjach $\mathrm{w}$ odniesieniu do tematyki nadzoru nad tymi podmiotami są paralelne.

Analizując ustawę Prawo o stowarzyszeniach, należy wskazać, że według art. 8 ust. 5 cytowanej ustawy organem nadzorującym działalność

28 Ustawa z dnia 6 czerwca 1997 r. - Kodeks postępowania karnego, tekst jednolity: Dz. U. z 2020 r. poz. 30 z późn. zm. (dalej: K.p.k.).

29 Ustawa z dnia 17 listopada 1964 r. - Kodeks postępowania cywilnego, tekst jednolity: Dz. U. z 2020 r. poz. 1575 z późn. zm. (dalej: K.p.c.).

30 Ustawa z dnia 30 sierpnia 2002 r. - Prawo o postępowaniu przed sądami administracyjnymi, tekst jednolity: Dz. U. z 2019 r. poz. 2325 z późn. zm.

31 Ustawa z dnia 7 kwietnia 1989 r. - Prawo o stowarzyszeniach, tekst jednolity: Dz. U. z 2020 r. poz. 2261.

32 Ustawa z dnia 6 kwietnia 1984 r. o fundacjach, tekst jednolity: Dz. U. z 2020 r. poz. 2167.

33 K. Peter-Bombik, S. Sadowska, Konflikty ekologiczne a partycypacja publiczna, w: Prawne instrumenty ochrony środowiska, red. B. Jeżyńska, E. Kruk, Lublin 2016, s. 104. 
stowarzyszeń jest starosta oraz wojewoda ${ }^{34}$. W rozważanym przypadku znaczenie będzie miała działalność starosty jako organu nadzorującego, ponieważ jest on właściwy we wszystkich przypadkach, w których nie działa wojewoda sprawujący nadzór nad działalnością stowarzyszeń jednostek samorządu terytorialnego. Jedynym kryterium nadzoru jest legalność, tj. zgodność działania stowarzyszeń z przepisami prawa i postanowieniami statutu (art. 25 ust. 1 ustawy Prawo o stowarzyszeniach). Oznacza to, że starosta nie ma prawa sprawować nadzoru merytorycznego. Mimo że starosta został uznany za organ nadzorujący, jego kompetencje $\mathrm{w}$ tym zakresie mają jedynie charakter kontrolny ${ }^{35}$. W zasadzie to sąd jest organem nadzorującym. Katalog środków kontrolno-nadzorczych zawiera ustawa Prawo o stowarzyszeniach w art. 29 w zw. z art. 28 oraz art. 31. Jest to wyliczenie enumeratywne. Wśród instrumentów nadzoru można wyróżnić środki stosowane przez organy nadzorujące oraz przez sąd. W razie stwierdzenia, że działalność stowarzyszenia jest niezgodna z prawem lub narusza postanowienia statutu organ nadzorujący, w zależności od rodzaju i stopnia stwierdzonych nieprawidłowości, może wystąpić o ich usunięcie w określonym terminie, udzielić ostrzeżenia władzom stowarzyszenia lub wystąpić do sądu o zastosowanie środka wskazanego w art. 29 ustawy Prawo o stowarzyszeniach. Jeżeli dojdzie do tego typu nadużyć, to starosta może np. żądać niezbędnych wyjaśnień od władz stowarzyszenia (art. 25 ust. 2 pkt 2 ustawy Prawo o stowarzyszeniach) ${ }^{36}$. Organ nadzorujący jest jednak obowiązany wskazać uzasadnienie powyższych żądań. Według art. 26 ustawy Prawo o stowarzyszeniach w przypadku niezastosowania się stowarzyszenia do wyżej wskazanych żądań sąd, na wniosek organu nadzorującego, może nałożyć grzywnę w wysokości jednorazowo nieprzekraczającej 5000 zł. Od grzywny można zwolnić, jeżeli po jej wymierzeniu stowarzyszenie niezwłocznie zastosuje się do żądań organu nadzorującego. Stowarzyszenie, w terminie 7 dni, może wystąpić do sądu o zwolnienie od grzywny. Poza tym sąd na wniosek starosty może udzielić upomnienia władzom stowarzyszenia, uchylić niezgodną z prawem lub statutem uchwałę stowarzyszenia, a nawet

34 E. Hadrowicz, Stowarzyszenia zwykłe w polskim systemie prawnym, Torun 2014, s. 130.

35 H. Izdebski, Fundacje i stowarzyszenia. Komentarz, orzecznictwo, skorowidz, Łomianki 2003, s. 114.

36 M. Supera-Markowska, Podstawy prawne tworzenia i funkcjonowania organizacji pozarzadowych, Warszawa 2015, s. 39 i n. 
rozwiązać stowarzyszenie, jeżeli jego działalność wykazuje rażące lub uporczywe naruszanie prawa albo postanowień statutu i nie ma warunków do przywrócenia działalności zgodnej z prawem lub statutem (art. 29 ust. 1 ustawy Prawo o stowarzyszeniach).

Patrząc na powyższe regulacje, można stwierdzić, że nadużywanie prawa do sądu czy też udziału w postępowaniu administracyjnym przez stowarzyszenie może polegać na działalności sprzecznej z przepisami prawa, np. ustawą o udostępnianiu informacji o środowisku i jego ochronie, udziale społeczeństwa w ochronie środowiska oraz o ocenach oddziaływania na środowisko. Nadużywanie prawa do sądu bądź prawa do udziału w postępowaniu administracyjnym wymagającym udziału społeczeństwa to również działanie niezgodne ze statutem stowarzyszenia. Organ wykonujący nadzór nie jest jednak w zasadzie upoważniony do interpretowania statutu. Zadanie to leży w gestii właściwych organów stowarzyszenia. Organ nadzorujący i sąd mogą tylko oceniać, czy interpretacja przyjęta przez stowarzyszenie odpowiada aktualnym przepisom prawa.

Ustawa o fundacjach, w przeciwieństwie do ustawy Prawo o stowarzyszeniach, nie posługuje się terminem „nadzór", aczkolwiek analiza regulacji wynikającej z art. 12-14 ustawy o fundacjach wykazuje podobieństwo do innych ustawowych przepisów dotyczących nadzoru. W związku z tym należy wskazać, że w wymienionych przepisach uregulowano instytucję „nadzoru” ${ }^{37}$. Organem nadzoru nad fundacjami jest przede wszystkim starosta właściwy ze względu na siedzibę fundacji ${ }^{38}$. Środki nadzoru stosuje zasadniczo sąd. Uprawnienia organów nadzoru ograniczają się jedynie do występowania do sądu z wnioskami o zastosowanie odpowiedniego środka nadzoru oraz do określonego w art. 14 ust. 1 ustawy o fundacjach wyznaczania terminu usunięcia uchybień w działalności zarządu albo do żądania dokonania w wyznaczonym terminie zmiany zarządu. Istotne znaczenie dla analizowanej kwestii ma art. 13 ustawy o fundacjach. Zgodnie z nim organ nadzoru może wystąpić do sądu o uchylenie uchwały zarządu fundacji, pozostającej w rażącej sprzeczności z jej celem albo z postanowieniami statutu fundacji lub z przepisami prawa. Organ ten może jednocześnie zwrócić się do sądu o wstrzymanie

37 M. Swora, Nadzór nad stowarzyszeniami, fundacjami oraz prowadzeniem działalności pożytku publicznego, Państwo i Prawo 2003, z. 12, s. 71.

38 P. Staszczyk, Ustawa o fundacjach. Komentarz praktyczny, Warszawa 2015, s. 106. 
wykonania uchwały do czasu rozstrzygnięcia sprawy. Istotne znaczenie dla tytułowej tematyki ma rażąca sprzeczność uchwały z celem fundacji albo postanowieniami statutu lub z przepisami prawa. Oznacza to, że jeżeli celem fundacji jest ochrona środowiska, a uchwała w sposób rażący narusza te kwestie, to sąd może wstrzymać wykonanie takiej uchwały. W praktyce jest to bardzo ważny instrument dla ochrony środowiska, wyznaczający granice działania takiej fundacji. Należy podkreślić, że nie każda sprzeczność będzie prowadziła do wstrzymania uchwały, jedynie sprzeczność mająca charakter rażący. Kompetencje sądu mają charakter kasacyjny, bada on legalność podjętej uchwały, lecz nie bada jej merytorycznej zasadności ${ }^{39}$. Jeżeli działanie zarządu fundacji w istotny sposób narusza przepisy prawa lub postanowienia statutu albo jest niezgodne z jej celem, organ nadzoru może wyznaczyć odpowiedni termin do usunięcia tych uchybień $\mathrm{w}$ działalności zarządu albo może żądać dokonania w wyznaczonym terminie zmiany zarządu fundacji (art. 14 ust. 1 ustawy o fundacjach). Po bezskutecznym upływie wyznaczonego terminu albo w razie dalszego uporczywego działania zarządu fundacji w sposób niezgodny z prawem, statutem lub celem fundacji organ nadzorujący może wystąpić do sądu o zawieszenie zarządu fundacji i wyznaczenie zarządcy przymusowego (art. 14 ust. 2 ustawy o fundacjach). Jeżeli powyższe działania zostaną zaniechane, postanowienie o zawieszeniu zarządu fundacji i wyznaczeniu zarządcy przymusowego sąd uchyla na wniosek zarządu fundacji (art. 14 ust. 4 ustawy o fundacjach).

$\mathrm{Na}$ zakończenie prowadzonych badań wypada wspomnieć także o ustawie o działalności pożytku publicznego i wolontariacie ${ }^{40}$, gdyż w świetle tego aktu stowarzyszenia i fundacje mogą uzyskać status organizacji pożytku publicznego (art. 22) ${ }^{41}$. Ważne są przesłanki warunkujące utratę takiego statusu (art. 22 ust. 4), przy czym utrata wyżej wskazanego statusu przez stowarzyszenie czy fundację nie eliminuje ich $z$ obrotu prawnego. Mogą one dalej funkcjonować na zasadach stowarzyszenia czy fundacji, nie mając statusu organizacji pożytku publicznego.

39 P. Suski, Stowarzyszenia i fundacje, Warszawa 2018, s. 488.

40 Ustawa z dnia 24 kwietnia 2003 r. o działalności pożytku publicznego i wolontariacie, tekst jednolity: Dz. U. z 2020 r. poz. 1057.

${ }^{41}$ R. Barański, Fundacje i stowarzyszenia. Wspótpraca organizacji pozarzadowych z administracja publiczna, wyd. 3, Warszawa 2016. 


\section{Zakończenie}

Konstatując przeprowadzone rozważania można stwierdzić, że organizacje ekologiczne działają $\mathrm{w}$ interesie publicznym dla dobra środowiska. Przepisy ustawy o udostępnianiu informacji o środowisku i jego ochronie, udziale społeczeństwa w ochronie środowiska oraz o ocenach oddziaływania na środowisko wyraźnie wskazują, jakie wymagania muszą spełnić organizacje ekologiczne, aby mogły występować w określonym postępowaniu. Elementy te nie budzą wątpliwości. Są one przedstawione w sposób precyzyjny i wyczerpujący.

Organizacje ekologiczne nie zawsze aprobują postępowanie inwestorów. Z uwagi na to, że podmioty te mają szeroką legitymację procesową, granice ich działania powinny być jasne. Zasięg działalności organizacji ekologicznych wyznaczają środki kontrolno-nadzorcze wynikające z przepisów ogólnych (ustawy Prawo o stowarzyszeniach, ustawy o fundacjach), gdyż ustawa o udostępnianiu informacji o środowisku i jego ochronie, udziale społeczeństwa w ochronie środowiska oraz o ocenach oddziaływania na środowisko nie zna takich instrumentów. Jest to słuszne podejście polskiego ustawodawcy i świadczy o jego dojrzałości legislacyjnej. Tego rodzaju rozwiązania wpływają na konsolidację prawa, a nie na jego rozczłonkowywanie czy fragmentaryzację. Nie są zatem potrzebne odrębne unormowania dotyczące kwestii nadzoru nad organizacjami ekologicznymi w ustawie o udostępnianiu informacji o środowisku i jego ochronie, udziale społeczeństwa w ochronie środowiska oraz o ocenach oddziaływania na środowisko. Nadzór nad stowarzyszeniami i fundacjami, wynikający z ustawy Prawo o stowarzyszeniach i ustawy o fundacjach, uregulowany został precyzyjnie. Ponadto ustawodawca należycie unormował zastosowanie określonych środków kontrolno-nadzorczych, co do zasady w sposób uznaniowy. Nie powinno ograniczać się subiektywnej oceny ze strony organu nadzorującego.

Niekiedy organizacje ekologiczne działają w sposób niezgodny z etyką środowiskową. Aby usprawnić działanie organizacji ekologicznych w określonych postępowaniach, należałoby postulować stworzenie unijnego kodeksu etycznego organizacji ekologicznych, który obowiązywałby wszystkie tego typu organizacje działające na terenie Unii Europejskiej ${ }^{42}$.

${ }^{42}$ Nie jest to odosobniony pogląd. Podobnie uważają M. Bar, J. Jendrośka, K. Tarnacka, zob. tychże, Prawo do sądu w ochronie środowiska, Wrocław 2002, s. 43. 
Mogłoby to wyglądać w ten sposób, że organizacja podpisałaby taki dokument w momencie powstawania. Nad jego przestrzeganiem czuwałaby określona unijna komisja specjalna utworzona przez ogół organizacji. Kodeks taki przyczyniłyby się także do zahamowania przyczyn kryzysu ekologicznego, jaki przeżywa współczesny świat, wypracowania najlepszych koncepcji jego rozwiązania oraz skonstruowania takiej filozofii rozwoju, która uwzględniałaby zarówno potrzeby człowieka, jak i przyrody ${ }^{43}$.

\section{Bibliografia}

Bar M., Jendrośka J., Tarnacka K., Prawo do sądu w ochronie środowiska, Wroclaw 2002.

Barański R., Fundacje i stowarzyszenia. Wspótpraca organizacji pozarządowych z administracja publiczna, wyd. 3, Warszawa 2016.

Barczak A., Łazor M., Ogonowska A., Oceny oddziaływania na środowisko w prawie polskim ze wzorami dokumentów i schematami, Warszawa 2018.

Barczak A., Ogonowska A., Wykładnia przepisów w zakresie udziału społeczeństwa w ochronie środowiska - wybrane problemy, Studia Prawnicze KUL 2018, nr 3.

Bąkowski T., Uznanie fundacji za organizacje spoteczna w postępowaniu przed sądami administracyjnymi. Glosa do uchwaty NSA z dnia 12 grudnia 2005 r., II OPS 4/05, Gdańskie Studia Prawnicze - Przegląd Orzecznictwa 2007, nr 2.

Borkowski J., Glosa do wyroku NSA z dnia 23 listopada 1999 r., II SA Kr 1191/99, OSP 2000, z. 7-8, poz. 112.

Chróścielewski W., Tarno J.P., Postępowanie administracyjne. Zagadnienia podstawowe, Warszawa 2002.

Daniel P., Udziat organizacji ekologicznej w postępowaniu w przedmiocie wydania decyzji o pozwoleniu na budowe, Przegląd Prawa Ochrony Środowiska 2012, nr 4.

Draniewicz B., Glosa do wyroku WSA w Krakowie z 22.07.2012 r. II Sa/Kr 272/10, Prawo i Środowisko 2010, nr 3.

Draniewicz B., Udział organizacji ekologicznej w postępowaniu niewymagajacym udziatu społeczeństwa, Prawo i Środowisko 2010, nr 3.

Draniewicz B., Uprawnienia organizacji ekologicznych w postepowaniach wymagajacych udziału społeczeństwa, Monitor Prawniczy 2011, nr 1.

Federczyk W., Organizacja ekologiczna jako uczestnik postęowania administracyjnego w zakresie ochrony środowiska, Kwartalnik Prawa Publicznego 2008, t. 8, nr 3-4.

43 W. Tyburski, Etyka środowiskowa i jej stan w Polsce, w: Księga Pamiątkowa Profesora Ryszarda Paczuskiego, red. Z. Bukowski, Torun 2004, s. 366. 
Flaga-Gieruszyńska K., Udział organizacji pozarządowych w postępowaniu w sprawach cywilnych z zakresu ochrony środowiska, w: Administracja a środowisko. Prace dedykowane prof. zw. dr. hab. Markowi Górskiemu z okazji jubileuszu 45-lecia pracy naukowej, red. A. Barczak, P. Korzeniowski, Szczecin 2018.

Górski M., Aktualne regulacje prawne w zakresie ochrony środowiska wedtug stanu prawnego na koniec stycznia 2009 r., Poznań 2009.

Górski M., Pchałek M., Radecki W., Jerzmański J., Bar M., Urban S., Jendrośka J., Prawo ochrony środowiska. Komentarz, Warszawa 2019.

Górski M., w: Ustawa - Prawo ochrony środowiska. Komentarz, red. J. Jendrośka, Wrocław 2001.

Gruszecki K., Ustawa o udostęnianiu informacji o środowisku i jego ochronie, udziale społeczeństwa w ochronie środowiska oraz o ocenach oddziaływania na środowisko. Komentarz, Wrocław 2009.

Hadrowicz E., Stowarzyszenia zwykłe w polskim systemie prawnym, Torun 2014.

Haładyj A., Organizacje społeczne i ekologiczne w postepowaniu w sprawie ochrony środowiska w latach 1980-2000, w: Administracja a środowisko. Prace dedykowane prof. zw. dr. hab. Markowi Górskiemu z okazji jubileuszu 45-lecia pracy naukowej, red. A. Barczak, P. Korzeniowski, Szczecin 2018.

Izdebski H., Fundacje i stowarzyszenia. Komentarz, orzecznictwo, skorowidz, Łomianki 2003.

Jabłoński M., Realizacja przez administracje publiczna prawa udziału społeczeństwa $w$ postępowaniu $w$ sprawie ochrony środowiska, w: Ocena modelu prawnego organizacji ochrony środowiska w Polsce i na Słowacji, red. E. Ura, J. Stelmasiak, S. Pieprzny, Rzeszów 2012.

Jacyno W., Rewkowska J., w: Ustawa o udostepnianiu informacji o środowisku i jego ochronie, udziale społeczeństwa w ochronie środowiska oraz o ocenach oddziatywania na środowisko. Komentarz, red. T. Filipowicz, A. Plucińska-Filipowicz, M. Wierzbowski, Warszawa 2017.

Lipiński A., Prawne podstawy ochrony środowiska, Warszawa 2010.

Lisicka H., Organizacje ekologiczne a prawo, w: Księga Pamiątkowa Profesora Ryszarda Paczuskiego, red. Z. Bukowski, Torun 2004.

Milewski P., Status prawny organizacji ekologicznych w ujęciu porównawczym, Kwartalnik Prawa Publicznego 2008, t. 8, nr 3-4.

Opaliński B., w: Ustawa o udostęnianiu informacji o środowisku i jego ochronie, udziale społeczeństwa w ochronie środowiska oraz o ocenach oddziatywania na środowisko. Komentarz, red. B. Opaliński, Warszawa 2016.

Parchomiuk J., Nadużycie prawa w prawie administracyjnym, Warszawa 2018.

Peter-Bombik K., Sadowska S., Konflikty ekologiczne a partycypacja publiczna, w: Prawne instrumenty ochrony środowiska, red. B. Jeżyńska, E. Kruk, Lublin 2016.

Radecki W., w: Ustawa o ochronie i kształtowaniu środowiska. Komentarz, red. J. Sommer, t. 1, Wrocław 1999. 
Rakoczy B., w: Leksykon ochrony środowiska, red. J. Ciechanowicz-McLean, Warszawa 2009.

Skrzydło-Niżnik I., Glosa do uchwały NSA z dnia 12 grudnia 2005 r., II OPS 4/05, Przegląd Sejmowy 2006, nr 2.

Staszczyk P., Ustawa o fundacjach. Komentarz praktyczny, Warszawa 2015.

Supera-Markowska M., Podstawy prawne tworzenia i funkcjonowania organizacji pozarządowych, Warszawa 2015.

Suski P., Stowarzyszenia i fundacje, Warszawa 2018.

Swora M., Nadzór nad stowarzyszeniami, fundacjami oraz prowadzeniem działalności pożytku publicznego, Państwo i Prawo 2003, z. 12.

Tarno J.P., Glosa do uchwaty siedmiu sędziów Naczelnego Sądu Administracyjnego $z$ dnia 12 grudnia 2005 r. (sygn. akt II OPS 4/05) (udział fundacji jako organizacji społecznej w postepowaniu sądowym), Zeszyty Naukowe Sądownictwa Administracyjnego 2006, nr 1.

Trzcińska D., Pojęcie organizacji ekologicznej. Glosa do wyroku WSA w Krakowie z dnia 14 kwietnia 2010, II SA/Kr 1774/09, Gdańskie Studia Prawnicze - Przegląd Orzecznictwa 2011, nr 2.

Tyburski W., Etyka środowiskowa i jej stan w Polsce, w: Księga Pamiątkowa Profesora Ryszarda Paczuskiego, red. Z. Bukowski, Torun 2004.

Wilk-Ilewicz A., Udział społeczeństwa w procesie uzyskania decyzji środowiskowej, Zeszyty Naukowe Sądownictwa Administracyjnego 2015, nr 5.

Zieliński A., Udział fundacji w postępowaniu sądowoadministracyjnym. Glosa do uchwały NSA z dnia 12 grudnia 2005 r., II OPS 4/05, Państwo i Prawo 2006, z. 8.

\section{Streszczenie}

Udział organizacji ekologicznej w ochronie środowiska ma kluczowe znaczenie w postępowaniu wymagającym udziału społeczeństwa. Organizacja ta w postępowaniu administracyjnym, sądowym czy sądowo-administracyjnym występuje $\mathrm{w}$ interesie publicznym, posiadając szeroką legitymację procesową. $\mathrm{W}$ działalności organizacji ekologicznej dochodzi czasami do nadużyć prawa publicznego, dlatego też regulacje prawne powinny zawierać unormowania utrudniające ich nielegalne działanie. Celem niniejszego artykułu jest zwrócenie uwagi na środki prawne hamujące działania prowadzące do nadużyć przez te organizacje.

Słowa kluczowe: ochrona środowiska, udział społeczeństwa, organizacje ekologiczne, nadzór 


\section{THE INVOLVEMENT OF ECOLOGICAL ORGANIZATIONS IN ENVIRONMENTAL PROTECTION AND THE LIMITS OF EXERCISING THEIR RIGHTS TO PARTICIPATE IN PROCEEDINGS REQUIRING PUBLIC PARTICIPATION}

\section{Sum mary}

The involvement of ecological organizations in environmental protection is of key importance in proceedings requiring public participation. These organizations, in administrative, judicial or judicial and administrative proceedings, act in the public interest with broad standing. Sometimes, violations of public law occur in the activity of these entities, which is why legal regulations should include norms hindering their illegal operation. The purpose of this article is to draw attention to legal measures that inhibit actions leading to abuse by these organizations.

Key words: environmental Protection, public participation, ecological organizations, supervision

\section{УЧАСТИЕ ЭКОЛОГИЧЕСКИХ ОРГАНИЗАЦИЙ В ОХРАНЕ ОКРУЖАЮЩЕЙ СРЕДЫ И ПРЕДЕЛЫ РЕАЛИЗАЦИИ ИМИ ПРАВА НА УЧАСТИЕ В ПРОЦЕДУРАХ, ТРЕБУЮЩИХ УЧАСТИЯ ОБЩЕСТВЕННОСТИ}

\section{Резюме}

Участие экологической организации в охране окружающей среды имеет ключевое значение при процедурах, требующих участия общественности. В административных, судебных или судебно-административных производствах эта организация действует в общественных интересах и имеет право выступать стороной в судебных процессах. В деятельности экологических организаций иногда нарушается публичное право, поэтому правовые нормы должны содержать положения, препятствующие их незаконной деятельности. Цель настоящей статьи - привлечь внимание к правовым мерам, препятствующим деятельности, ведущей к злоупотреблениям со стороны этих организаций.

Ключевые слова: охрана окружающей среды, участие общественности, экологические организации, надзор 